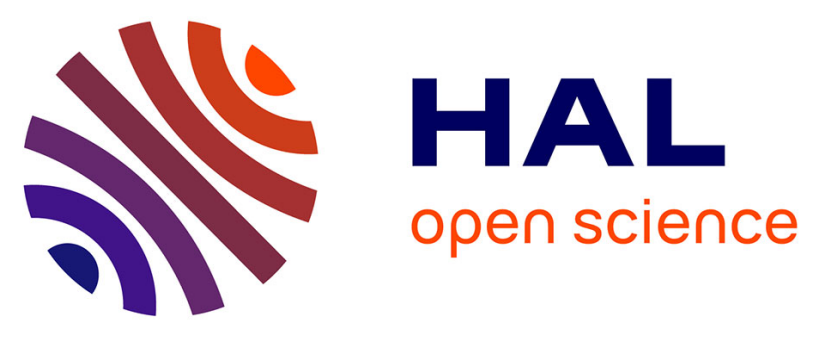

\title{
Physical Education as a Subject in France (School Curriculum, Policies and Discourse): The Body and the Metaphors of the Engine-Elements Used in the Analysis of a Power and Control System during the Second Industrial Revolution
}

Jacques Gleyse, Charles Pigeassou, Anne Marcellini, Eric de Léséleuc, Gilles Bui-Xuân

\section{- To cite this version:}

Jacques Gleyse, Charles Pigeassou, Anne Marcellini, Eric de Léséleuc, Gilles Bui-Xuân. Physical Education as a Subject in France (School Curriculum, Policies and Discourse): The Body and the Metaphors of the Engine-Elements Used in the Analysis of a Power and Control System during the Second Industrial Revolution. Sport, Education and Society, 2002, 7 (1), pp.5-23. 10.1080/13573320120113549 . hal-01334332

\author{
HAL Id: hal-01334332 \\ https://hal.science/hal-01334332
}

Submitted on 21 Jun 2016

HAL is a multi-disciplinary open access archive for the deposit and dissemination of scientific research documents, whether they are published or not. The documents may come from teaching and research institutions in France or abroad, or from public or private research centers.
L'archive ouverte pluridisciplinaire $\mathbf{H A L}$, est destinée au dépôt et à la diffusion de documents scientifiques de niveau recherche, publiés ou non, émanant des établissements d'enseignement et de recherche français ou étrangers, des laboratoires publics ou privés. 
Ph.D. Profs. J. Gleyse, C. Pigeassou, A. Marcellini, E. De Léséleuc, G. Bui-Xuân, Corps et Culture. Montpellier, France.

Professional address: Jacques Gleyse, I.U.F.M., 2 place Marcel Godechot, 34000 Montpellier, France

Email jacques.gleyse@wanadoo.fr 


\title{
Physical Education as a subject in France (school curriculum, policies and discourse). The Body and the Metaphors of the Engine
}

\section{Elements used in the analysis of a power and control system during the Second Industrial Revolution. ${ }^{1}$}

Key words: Metaphors, mythology, systems of control, Physical Education, the body.

\begin{abstract}
:
\end{abstract}
An analysis of several works by people who contributed greatly to the development of physical education in France from the middle of the 19th century to the 1960s enables us to pinpoint the rules underlying the specialized language used in this field and the metaphorical and mythological systems that were set up as systems of control over the body. Among these images, it is particularly interesting to examine how 'man' came to be seen in terms of a steam engine, then as a machine, and even more generally as a humanized form of "productivity".

\section{Introduction}

By taking a look at the history of physical education light is often thrown on what is happening now. And this is so for all the aspects that combine to make up this school discipline in France as elsewhere in Europe.

Our interest here is to review the language employed in written school programs (1996, 1997, 1998, 1999 and 2000) as well as the current practices and the many articles appearing in EPS (a revue that circulates widely among physical education and sports teachers in France), under such headings as "Maximum Aerobic Speed", "Maximum V.O.2" and "Maximum Aerobic Force" which basically refer to energetic sports activities, such activities being a far from insignificant part of the practices evaluated in the school

\footnotetext{
${ }^{1}$ Thank you very much to Jean Godwin for helping us in translating from french but also to Susan Watson.
} 
curriculum. Eight physical activities are available in "collège" [for children between 11 and 15 years of age]: athletics, gymnastics, open air activities, water and physically artistic activities, dueling, racquet and team sports and games. In particular, long distance running has always been pursued and is practiced in these establishments today; it is probably one of the activities most deeply rooted in the historical discourse being analyzed here. The tests used in this domain (Luc Leger, Cooper and the step test) are entirely the outcome of a peculiarly "energetic" perception of the body. But competitive swimming and certain openair activities (such as orientation races and cross-country cycling) are also in part the outcome of this same perception. Activities such as aerobics, step, and stretching, that are little practiced in schools in France, doubtless have the same theoretical origin.

The discourse that provides the springboard for the practice of these activities, despite considerable revision of the vocabulary, is based on metaphors that were employed by the sages in their language in the 19th century. It is therefore interesting to try and evaluate the extent to which the metaphors used primarily relate to the period during which they were writing, in other words, to the Second Industrial Revolution. And it is equally interesting to realize that such a discourse has survived and serves in practical applications in a very different context, in a society which is very largely "informational", "communicational" and even cybernetic (Fourastié, 1979) and "spectator-orientated" (Debord, 1967) and no longer industrial.

It is thus a remarkable story that is being explored here, tracing those aspects of the discourse held in France on physical and sports education which actually became incorporated into the school curriculum at the turn of the century, we are not concerned with the totality of the theories and practices that go to make up this discipline.

The studies by David Kirk (with Richard Tinning: 1990 and 1998) perfectly evaluate how physical education was built up as a school subject in England and Australia. These authors show how the history of the discipline related to social life and also how it is a key area in the production of cultural mores and value systems.

In France too, many studies have been devoted to examining the history of the discipline in schools. Research by Pierre Arnaud (1983) comes to mind, demonstrating the relationship between this discipline and changes in the State school system; by Gilbert Andrieu (1990) showing how it is a "total social fact"; and more recently the research carried out by Cécile Collinet (2000) analyzing the inner structure of the language used in 
speaking of physical education; Jean-Luc Martin (1999) describes its dependence on the political arena in a fairly recent period; and Philippe Liotard (1999) who refers to the discourse held on physical and sports education in the 20th century in France as if it were basically a system of religious belief. The studies undertaken by Jacques Gleyse (1995, 1997 and 1999) have clearly shown the dependence on, or at least a very decided interaction between modes of work, conception in education and the discourse held on the subject of physical education.

Yet little work in the English language has shown an interest in this field. J. Holt in the United States has devoted several papers to the subject, in particular, for example in The Journal of Sport History (1991). Some papers have also appeared in the review The International Journal of the History of Sport and in The European Sports History Review. However, it seems that Sport Education and Society has no place for this field of research into physical and sports education. Recently, work has appeared on Physical Education in Hong Kong (Shuttleworth \& Chan Wan-Ka (1998) and in Africa (Shehu, 1996) but none on France.

In any case, what follows is not concerned with rewriting the overall history of physical and sports education in France, which has been written a number of times in French. Its intent is rather to show specifically how, in the heart of the discourse being held on this same subject from the mid 19th century to the beginning of the nineteen fifties, the metaphors of the simple machine (lever, pulley or screw) and of mechanics devolving in particular from the field of natural and technical sciences, were to express and often to influence the reality of the practices put into effect and sometimes even the programs and policies themselves. Systems of metaphor that relate to Foucault's theories (Foucault, 1975), might be thought of as corporal control systems, persisting yet transforming over time, but they might also be seen as the "social" expression of a particular domain.

However, before explaining the language used, a brief detour is essential to enable the reader to understand the theoretical basis for what is applied subsequently, and also to identify the difference or correlation between the scientific and technical-scientific analyses of the discourse held on movement and practices in the programs available and the State policies developed.

It is also essential to draw the attention of the English speaking reader to the major stages in the construction and double modes in the school discipline in France as it 
appeared in the studies cited above.

\section{Prior historyPrograms and policies in gymnastics and physical education from the Restoration to the Third Republic}

\section{Premise.}

A civil and military gymnasium was founded in 1815 by Napoleon's Colonel Amoros y Ondeano and from these beginnings an embryo gymnastic organization developed in the city of Paris.

Yet it was not until October $21^{\text {st }} 1845$, under the July Monarchy of Louis-Philippe I, that ministerial commissions (Narcisse Salvandy was then Minister of Public Instruction for Fine Art and Worship), started to focus on the teaching of gymnastics in the Royal junior and secondary schools. However, these commissions had practically no effect in terms of the State.

The same situation was the same for the commissions appointed under the Second Empire, from 7 November 1853. Even though these led to a formal report and the First Regulation on Teaching Gymnastics in Secondary Schools on March $13^{\text {th }} 1854$ which stated that: "gymnastics forms part of the instruction given in secondary schools and it is regularly taught at the expense of the establishment", neither tangible benefit nor legislation resulted.

\section{The first effects. Military gymnastics.}

By contrast, the Hillairet commission (named after its chairman) appointed on $15^{\text {th }}$ February 1868 , submitted a very substantial report, referring to the almost total absence of facilities (a gymnasium for an average of about 8 establishments and only one teacher for some 450 pupils; the current norm is one teacher for an average of 140 pupils). Yet there was an accumulated backwardness by comparison with our neighbors such as Sweden, Switzerland, Germany and Denmark which were already generally equipped with gymnasiums. This report led to the creation of a teaching diploma (the Certificate of Aptitude for Teaching Gymnastics - the CAEG) on November $25^{\text {th }} 1869$ and to the first school program (on February $1^{\text {st }} 1869$ ) for the Imperial junior and secondary schools and to primary school teacher training in the "Ecoles Normales". These programs were mainly based on "mechanical" and military gymnastics, meaning on exercises that were largely inspired by the first proposals made by Frédérico Amoros at the beginning of the 19th century. A sort of basic ABC of gestures applied here. Gymnastics was ground-based and was often "segmented" with each limb or muscle being exercised individually. 
These exercises of application were the most suitable exercises for military combat using the bayonet, club or saber as well as for attacking trenches and fortifications. It should be noted that during this period there was no civilian teacher training school.

It is worth mentioning, however, that in the military domain, a gymnastics school an "Ecole supérieure" - was inaugurated at Joinville, on July $15^{\text {th }} 1852$ which provided basic training in gymnastics until the beginning of the 20th century. Primary school teachers, whose role first appeared with the creation by Guizot of the "Ecoles Normales" in 1830, sometimes obtained an acceptable training in them during their long period of military service (three and a half years). But in the main, former non-commissioned officers gave classes in secondary establishments.

\section{Adopting gymnastics in schools. Two approaches.}

The situation of school gymnastics was only modified at the very end of the 19th century with the Ferry Laws (voted on March 28th and June 16th 1882) which, by creating public, free, non-religious and compulsory schooling for 6 to 13 year olds, tried to encourage the introduction of gymnastics in school curricula. This venture divided the approach to schooling in France up until the end of the Second World War. On the one hand were schools for the general population with primary school, senior primary school, and the "Ecoles Normales" and "Normales supérieures", and the Certificate of Primary Studies, the Elementary Certificate and the Higher School Certificate. On the other hand, there was the school system for the upper class and the aristocracy with junior and secondary schools, which were often private, Catholic and fee-paying and led to the Baccalaureate and admission to university. This division also played a role in physical and sports education, as schools for the general population generally encouraged gymnastics whereas the private junior and secondary schools very rapidly incorporated sports, quite often on the initiative of the pupils and headmasters. The same division was also evident in the most important two associations set up the close of the 19th century, in 1888. The first of these was the "Jules Simon" Committee (in reality the committee for propagating physical exercise) which was pro-sport and whose secretary was Baron Pierre de Coubertin. The other was the French Physical Education League, comprised of Republicans and often of Free Masons such as Paschal Grousset, acolyte of Physical Renaissance, a "communard" and revolutionary socialist who was the elected representative for the $10^{\text {th }}$ district of Paris. 
On June $10^{\text {th }} 1879$, Senator George was entrusted with drafting the report of a commission chaired by Barthélémy de Saint-Hillaire. The purpose of this commission was to encourage the teaching of gymnastics in community schools which were free of charge and enrolled nearly 3.5 million French youngsters. In 1880 the commission published programs as well as a Handbook of Gymnastic and Military Exercises. The main purpose of these publications was to develop "school battalions" and to teach school children how to handle firearms. The gymnastics stipulated in these texts was mainly mechanical and ground-based. It was segmented and founded on models that were largely drawn from mechanical theory rather than from energy theory although the latter was beginning to gather momentum in the scientific world. In part because of the time disparity with scientific research into movement, and the work of Etienne-Jules Marey (1873) and Fernand Lagrange (1888) in particular, as well as through the gradual loss of influence of military authorities within the State, a new commission was appointed on October $18^{\text {th }}$ 1887to reform these programs and the Handbook. This commission was chaired by that eminent professor of the "Collège de France", Etienne-Jules Marey (we will refer to him again later) and it was quick to eliminate military exercises from gymnastics teaching. It brought out new programs on August $8^{\text {th }} 1890$ and soon followed these with a Handbook of Gymnastic Exercises and School Games which was published by Hachette at the very beginning of 1891 .

The military aspects of gymnastics were largely expurgated from the text and while ground-based and mechanical gymnastics remained generally present, games started to have a place in the program too, as well as an embryonic form of modern sports. The energy aspects of exercise were not really very clearly highlighted. The analysis of movement was mainly mechanical, despite the presence on the commission of Marey, Lagrange and Demenÿ (who carried out research into aspects of movement concerned with energy and output, as we shall see below).

Actually, a significant sea change was taking place with the publication in 1908 of the Handbook of Physical Exercises and Games for Schools, largely at the initiative of the same players and in the same context. This publication focused on a new analysis of movement notably in terms of "mechanics" and energy and it used metaphors that were more firmly founded on the idea, which had not appeared in earlier papers, of a "manmotor" or steam machine. 


\section{From gymnastics to physical education.}

The papers that appeared next, in particular the Military Regulations of January $21^{\text {st }}$ 1910 , followed by the Official Instructions of June $20^{\text {th }} 1923$ with allusions to the provisional programs of 1919, comprised the best of the "French method", based above all on an eclecticism incorporating the Swedish method (mechanical), the Demenÿ method (energy-production), the natural method (basically "fundamental" and the heritage of research conducted by Georges Hébert), with school games and a few hints at sports designed for the elderly.

The papers that appeared up to the nineteen-sixties made no great attempt to seriously question this orientation. On the contrary, a dramatic rupture occurred in 1962 when sport was imposed as essential in the teaching of physical education in junior and secondary schools. The Official Instructions issued in 1938, 1941, 1945 and 1959 remained above all built on this baroque eclecticism. Nevertheless, they largely incorporated the energy perspective and demonstrate a view of the body that is not only mechanical but is also thought of as having to produce an output, a yield (calculated in Watts, Joules and kilogram-meters per second).

Again, it was in 1941 that physical and sports education became an optional subject in the Baccalaureate. In 1959 it became a compulsory subject when taking this diploma (yet it had been compulsory as early as 1882 for the Primary Studies Certificate and in 1886 for the Higher School Certificate - taken at age 16). It may therefore be assumed that it was actually taught and evaluated from these dates.

\section{Teacher training.}

At the same time, a genuine, civilian State training for physical and sports education teachers and infant-school teachers was being made available. This training was firstly instituted in the Paris High School founded by Georges Demenÿ in 1903, and then in preparatory classes during school vacations for infant-school teachers holding a CAEG, a higher CAEG degree (corresponding to the level of studies matching the infant-school teachers' specialization) started in 1908. The crowning achievements took place in 1927 with the creation of Higher Institutes for Physical Education, which were attached to medical schools, and in 1933 with the opening of the (higher) "Ecole Normale" for Physical Education and the creation of a Certificate of Aptitude in Teaching Gymnastics awarded 
after three years of university studies and practice after the Baccalaureate and the Higher School Certificate. This training, initiated by medical researchers was to incorporate the latest knowledge available and in particular the bio-energetic perception of the body.

It is these concepts driven by a form of metaphor that we are now about to consider. It should, nonetheless, be stated that the actual practice of physical and sports education during these periods are much more difficult to analyze given the small amount of documented information available and the lack of other research into the subject.

Overall, it would seem that there were few infant-school teachers actually teaching this discipline during the period, particularly in rural areas, even though the programs stipulate a significant time-table (some four or five hours a week); and France was mainly rural in the 19th century as nearly $74.5 \%$ of the population lived on the land in 1851 and this figure remained $55.8 \%$, in 1911 .

In the secondary schools too, the recurrent absence of facilities led the older students to take up open air sports (rugby, running, athletics...), from very end of the 19th century and the start of the 20th century, while the assiduous practice of physical education seems to have been rare at least until the mid-twenties (on this subject, see Gay-Lescot, 1999).

\section{Prior theories. The bodytechnology and economics.}

From the middle of the 19th century onwards, theories concerning the steam engine and then energy as a concept in itself were explored; at the same time, a scientific paradigm (thermodynamics) developed, which, even though it was not entirely new, it nevertheless created a kind of revolution in appreciating how the body functioned and more specifically of its movement. The process of instrumental rationalization of the human body and movement, was linked, in part, to the industrialization of the world of work (Gleyse, 1995) and began in the 17th century during the French Classical period with René Descartes' 1664 A Treatise on Man (De homine figuris : Traité de l'homme). This process continued and developed with the biomechanical paradigm created by Borelli in 1685 in his work, "De motu animalium", and was given a second lease of life thanks to the exploitation of new models that were both mechanical and metaphorical. While the simple engine using natural forms of energy and the manufacturing process, close to that of the "work-shop", served as a model for the Cartesian mechanical body, the steam engine followed by the internal 
combustion engine were used by the most influential writers in this field for their theories about the body and human movement at the end of the 19th century.

Following on the work of Foucault $(1969,1971$ and 1976) and also that of Canguilhem (1989), this paper attempts to bring to light the metaphors, mythology and beliefs which helped to create the controls and value systems that supported this vision of "the body as machine" during the Second Industrial Revolution in France. A kind of archeological isomorphism is created that makes use not only the industrial world as a model during this period of expansion but also of the mechanical models that are associated with it. The locomotive, the steam engine and the machine are images that need no explanation of a technical order to find a parallel in the images used for the body. And so certain influential people, wishing to institute a particular type of society and social intercourse, promoted a vision of the body that corresponded with models provided by industrial machines.

It is possible to trace a kind of network of images starting from the first improvements in steam engines. We can follow this network through the theories of thermodynamics, to the application of these theories - in particular to 'man', in the work of Auguste Chauveau and Gustave Adolphe Hirn (1815-1890) - and what numerous writers came later to call The Animal Machine (La machine animale), E.J.Marey, 1873, and, The Living Engine (Le moteur vivant, P.Chauchard in 1957). This same idea is also found in 1985 in Paillard's work, with his metaphor of "piloting the human machine".

Our study is based on an analysis of the literature on the body, and not only on the subject of physical education, from the middle of the 19th century to the end of the 1950s in France. The texts that have been selected were all written by people of authority in the field of physical education and sport during this period. The documents referred to are scientific texts written by doctors who were interested in exercise and the body (Hirn, Lagrange and Marey), by official figureheads who played a decisive part in establishing physical education as a school subject (Demenÿ, Tissié and Labbé) or are extracts from official handbooks and regulations that paved the way for the practice of sport in schools.

The people whose names are quoted were, as previously mentioned, active members of Ministerial Committees (The Ministry of Public Instruction and Fine Arts). It was their task to lay the foundations for the legislated, regular practice of physical education as part of the "compulsory, non-religious and free" education that developed in France following 
the Jules Ferry laws (1880). It should be noted that the creation of the school subject, physical education, in its most characteristic form, seems peculiar to France and certain other European countries, whereas in Anglo-Saxon countries, for instance, it might be a modern sport that serves as physical activity in school. The analyses carried out by David Kirk (1990, 1998), does not however show significant differences between France and the United Kingdom, insofar as the general links between physical education and society and culture are concerned. The same is apparent in the work of Donald Guay $(1969,1981$, 2000) in Canada.

The technical progress represented by the steam engine seems important for the birth and development of the "human engine" paradigm as a model for interpreting the body, but the factory, where this progress was manifest, would also seem to play an important part in the creation of this particular logic. Behind the interpretation of the body as an "energy system" factory productivity is perhaps also visible - just as it is in the notion of the "Republican" school in intellectual subjects. The literature that tends to transform the body into an instrument (Gleyse, 1997), reveals to us the way in which 'man' was viewed socially and also reveals the standards by which he/she was measured in a powerful "dialogic" (Morin, 1986). It also shows us how the men (and they were almost invariably men) who possessed the power of decision or who exercised a considerable cultural weight perceived the general public.

A time lag can very definitely be discerned between the theory from which mechanical metaphors being studied arise and references in official texts and practices. In fact, the machine model of the body does not seem to become incorporated in the programs until the beginning of the 20th century, while scientific texts make references to it some fifty years earlier.

\section{Industry as a metaphor and means of control.}

"The function of the factory, whose forerunner was the work-shop, is to bend the will of that restive, unruly workforce, which is used to being master of its own work processes, and bring it to respect order and hierarchy and economy of gesture and word. We aim to limit the movement of the body in order to achieve a real control of industry through discipline" (Perrot, 1979, p.483). This quotation sums up perfectly the way in which changes in working methods brought about a change in the perception of the 
working body and the system of values attached to it, values that, themselves, would bring about a transformation in the way the body was and is physically exercised.

Gymnasiums, in the form in which they emerged at the end of the 18th century, represented, without any doubt "body factories". As for modern sport, as shown by J-M. Brohm (1976), it probably arose and developed in part along the lines of industrial capitalism, in both its mythological foundations as well as in its institutionalized structures. The standards that governed and the language that was used to designate the industrial body could not be dissociated from the body itself, and came to be defined in the field of physical education and more generally in the idea of exercise.

In 1832, in his work On the Economy of Machines and Factories, Charles Babbage described a paradigm that defined human productivity and the scientific organization of human work in factories as a fundamental element in industrial success. In 1855 JeanGustave Courcelle-Seuneuil published his Business Handbook (Manuel des Affaires), the first genuine treatise on the organization of industrial enterprises.

This trend ultimately led to Frederick Winslow Taylor's Scientific Management (1902). From 1890 onwards, he promoted the idea of the rational, scientific organization of human work making it possible, for instance, for the weight of cast-iron handled by a worker in a day to be increased from 12.5 to 67.5 tons. With this in mind, the movements of the human body were carefully separated, dissected even, into individual components. No time wasting of any sort was tolerated; the aim always being to achieve increased productivity. In addition, workers were to be given the tasks at which they were most efficient. This same process was certainly being applied to sport and more generally to exercise as a whole by the end of the 19th century (Gleyse, 1995 and 1997) and it probably reached its apogee in the 1950s and 1960s both within and outside the world of education (Bui-Xuân, 1989).

The similarity of the opinions of Frederick Winslow Taylor and Georges Demenÿ (1902) has been very clearly identified elsewhere (Gleyse, 1999) and enables the probability of validating the existence of a dialogue between the world of work and the world of physical education in school or at least in the sphere of discourse on the body (often related to physical education), even though it is involuntary and not deliberate. This viewpoint is quite close to the problematic raised by David Kirk. 


\section{The identification of the body with the steam engine.}

Let us rapidly consider the fact that a kind of genealogy has become established based on technical and scientific works (Gleyse, 1997, op. cit.). This genealogy started with Denis Papin's first attempt at producing a steam engine in 1690, continued with the granting of a patent to Savary in 1698 by the Royal Society of London, with Thomas Newcomen's more advanced theories at the beginning of the 18th century and, subsequently, with James Watt's achievements in 1770 . This genealogy finally brings us to the first application of these concepts in physics and chemistry to the human body, specifically by Lavoisier in 1774 in his Elementary Treatise on Chemistry (Traité elementaire de chimie). In 1824, Sardi Carnot's theories in his Reflections on the energy-producing power of fire (Reflexions sur la puissance motrice $d u$ feu) laid down the scientific basis for the paradigm which became the technology of the body by the end of the century. The image of the human body was brought even closer to the machine in Claude Bernard's work.

The idea of the rationalized energy-producing body, which appeared just when the machines that used natural sources of energy in the world of work were being gradually phased out ${ }^{2}$, was perhaps not only developed in part from the technology of the steam engine, but also through the economic need for more and more efficient factory production. At least we can perceive, as will be shown later, a metaphorical dialogue between these two types of language. But in both instances it would seem that of a group of pioneers was instigating a system of control over the general population.

\section{Gustave Hirn describes the man-engine.}

In the middle of the 19th century, following in the wake of Claude Bernard, doctors specializing in Physiology and energy radically modified the perception of the body. Among them, Gustave Hirn led the way by systematically applying ideas to the human body that in theory had been designed to improve the productivity of machines. He wrote: "Consequently, there is a MECHANICAL equivalent to work, and a CALORIFIC equivalent to heat" (Hirn, 1862, p.30). Once this idea had been established, nothing could prevent its application to the human body, as we see in G.A.Hirn's An Analytical and

\footnotetext{
${ }^{2}$ It should be noted that at the very beginning of the 19th century in France, $90 \%$ of energy was produced by 'men', animals or was a natural energy such as water or wind. By the beginning of the 20 th century, $70 \%$ came
} 
Experimental Commentary on the Theory of Heat (Exposition analytique et expérimentale de la théorie de la chaleur): "[...] what is just as clear now from the point of view of the mechanical theories on heat and electricity, or to state it even more plainly, from the pure and simple point of view of the laws of equilibrium, is that when we execute an external movement with the help of our limbs, we function like a machine". (Hirn, 1862, p.604607). A year later he developed this idea even further in his paper The Mechanical Theory of Heat (Théorie mécanique de la chaleur).

With Hirn, the paradigm of the steam engine - the result of experimenting in workshops - which was perfected by science, was given back to its source, 'man', through the way in which his/her body was transformed into a machine, an object, a rationalized instrument. In the industrial universe and in the factory environment 'man' became a theoretic entity in accordance with values represented firstly by the steam engine and then by the machine. As René Thom points out (1990), a kind of implacable logical cycle was set up: technology gave birth to science and then science, expanding beyond its first field of application, or else being applied (or even misapplied) to other fields, led in turn to the birth of a technology, or sometimes even a technocracy. It was the human body, or more particularly in this case the physical activity associated with it, that was the subject of this technology. But this technology should not just be considered as such; above all else it was a widespread system of control that organized society, or at least a system that a few influential people wished to promote for the greater good of the masses.

Auguste Chauveau (1837-1917), whose footsteps Hirn followed, had already outlined the basic rules for the establishment of a real system of ergonomics and physiology of work. Hirn consolidated this paradigm and applied it to corporal practices as a whole, going beyond the limited field of industrial production.

In his article entitled Thermodynamics and Work in Living Beings (La Thermodynamique et le travail chez les êtres vivants) which was published on the 28th May 1887 in Charles Richet's The Scientific Review (Revue Scientifique) (Revue Rose, p.673-684), Chauveau very clearly explained how he arrived at his conclusions and how they could be applied to all aspects of movement. In this article he related in particular the experiments he carried out in April and May 1857 and, basing his arguments on these, 
showed "what the true work of the living engine is" (p. 679). These experiments led him to conclude that "What we can state as far as the engines of the physical world are concerned can necessarily and completely be applied to organized machines, and [...] to the human machine, which we can study most easily and scientifically." (ibid.p.678). 'Man' was not therefore considered as an individual, as a person in his/her own right, but fully and thoroughly as an instrument that had to be made as productive as possible in terms of work and output.

Without questioning his own arguments, Hirn proceeded from inanimate nature to the generic 'man', from physics and chemistry to physiology, from the inanimate to the animate, from the mechanical to the living. This way of thinking brought to light the structure of a micro-power promoted by people with influential arguments. However, at the time he was writing, Hirn's position did not have a genuine spin-off in the domain of school gymnastics. The programs of his time can be seen as being mainly based on the theories of Borelli, where the body is made up of levers, of coupling forces and not of carbonated combustion. The machine metaphors remained the preserve of theoretic research. But that was gradually to change.

\section{Extending the new system of standards and control.}

Following on from G.A.Hirn, the paradigm of the animal machine and the system of corporal values that it entailed were reinforced and amplified in the language of the day. Paul Bert, a very influential Republican during the Third Republic, developed the paradigm of the physiology of work in his 1867 text The Human Machine (La machine humane) and this development gathered momentum in the research conducted from 1860 onwards by Etienne-Jules Marey (1830-1904, who as already explained, was an influential Republican and a Professor at the Collège de France). The introduction to the latter's work The Living Machine, Locomotion on Land and in the Air (La machine animale. Locomotion terrestre et aérienne) (1873) is enlightening on this subject: "Often and in every age living beings have been compared with machines, but it is only today that we can fully appreciate the soundness of this comparison [...] the comparison of animals to machines is not only legitimate, it is also exceedingly useful from various points of view" (ibid.p.V-VI). Chapter III of the same book, which dealt with "animal heat" (ibid.p.17) confirmed that the theory of the body as a machine capable of producing energy had become dominant and 
that following this, all human movement could be analyzed in the same way as a machine would be. In this paper we find Hirn's ideas from his 1887 article repeated practically word for word. Nevertheless, his ideas too were slow to penetrate programs and school handbooks, despite his chairing of commissions in the domain of school gymnastics, and it was only after his death that they bore more specific traces of them.

The same theories can be found in Fernand Lagrange's 1888 A Physiology of Corporal Exercises (Physiologie des exercices du corps). Lagrange was a doctor who sat on all the Ministerial Committees set up to put physical education firmly on the school curriculum. In Chapter III of his paper, he referred to "the human engine and heatproducing machines" (Lagrange, p.28) and in Chapter IV the problem of "combustion" was dealt with (Lagrange, p.36). As one example from among many, we quote this sentence: "the human body has been compared, as a source of movement, to a heat-powered machine. We know that no machine can create power. The most perfect engines can only transform one type of energy into another. The human engine transforms heat into movement" (Lagrange, 1888, p.28).

Scientific language and above all, the medical language used here, was aimed at imposing a system of values on the interpretation of the body which clearly led to 'man' being considered more as a tool or instrument, than as a person in his/her own right.

In 1890, only two years after Fernand Lagrange, Emile Couvreur, the director of the research laboratory at the Lyons University of Science (he was also, as has been shown, influential in establishing State physical education), published a paper entitled Exercising the Body (Les exercices du corps). Here he continued the same analogy and extended the paradigm and system of standardization. The whole of the first section of the text entitled "the animal machine and its mechanisms" was the logical follow-up to the system already defined. The third chapter of this same section, entitled "the job of the muscles" employed the system originally described by Gustave Adolphe Hirn. But this author's language as that of Etienne-Jules Marey, only seemed to be matched in the school policies, programs and perhaps practices after a certain time lag - at the beginning of the 20th century. His book Physiology and Bodily Exercise (Physiologie des exercices du corps) is however considered by many authors, including Georges Hébert, as a fundamental reference on the subject of energy. 


\section{Physical Education either is or is not "energy-producing".}

The above heading paraphrases the position Georges Demenÿ advanced in his work The Scientific Basis of Physical Education (Les Bases scientifiques de l'éducation physique) (1902) in which he effectively stated: "PE either is or is not scientific". In any event, his position was to reinforce and amplify the language studied previously, and it was substantiated by the fact that he succeeded in obtaining approval of his metaphoric bases by the commission that established the Handbook of Physical Exercise and Games in School 1908.

As a disciple and the spiritual child of P.Bert and E-J.Marey, Georges Demenÿ (1850-1917) is considered the father of physical education as a school subject in France and he naturally continued to explore this particularly flourishing avenue at the end of the 19th century and the beginning of the 20th. However, with this author, more than with those mentioned previously, the theories were refined and complex and the model of the steam engine was gradually replaced by those of the internal combustion engine and the petrol explosion engine as developed at the same time by Forest who, in 1899, devised the first 4cylinder petrol engine. A new metaphor then appeared to reinforce the system of values and the logic of language.

Georges Demenÿ wrote: "Our blood contains hydrocarbons similar to the oil burnt in our lamps, the coal burnt in our fires. It also contains oxygen which, as it combines with the former elements, causes their combustion providing a source of heat and energy. Muscular contraction and movement are the result of this physiological process. Willpower provokes movement just as an electric spark will provoke an explosion in an unstable volatile matter" (Demenÿ, 1902, p.12). Unlike other writers, Demenÿ was nevertheless extremely lucid in respect of the process that lay behind his theories. "It is absolutely clear that the aim of physical education must be to improve the individual, with a view to contributing to the progress of all men; it is an economic goal and its consequence will be a higher rate of productivity in useful work" (Demenÿ, 1890, p.355). Here we can see quite clearly how one of the great supporters of Republican politics during the Third Republic in France attempted to apply a particularly powerful system of coercion to the general public. In the field of physical education, the analogy of the human engine was very probably one of the means of surveillance and punishment and one of the many ways that a 
panoptic view integrated with and conformed to the needs of an economic system.

It is worth mentioning that this same idea of "a better use of energy" was also to be found in Japan, with the birth of Judo and the method of physical education being developed by Jigoro Kano in 1882. This would strongly support the theory that it was more a matter of imposing a system of standards and constraints relevant to the industrial world and the requirements of capital, than a purely parochial feature of French culture. The same type of "industrial" metaphor can be found in the English speaking countries, including Canada, at about the same time.

\section{Race and the human engine.}

Philippe Tissié however disagreed with Georges Demenÿ both on the subject of the methods to be employed and on the scientific basis for physical education but he too arrived at machine metaphors. Thus the same analysis can be found in the first chapter of Philippe Tissié's (1919) paper entitled Physical Education and Race. Work, Health, Longevity. (Education physique et la race. Travail, santé, longévité). This chapter is entitled "The human engine in gymnastics" (Tissié, p.7). Tissié founded the Physical Education League in Gironde (which later became the French Physical Education League) and he was a very significant figure in the sphere of State physical education in France. And yet the system of gymnastics that he advocated was based more on the theory of a mechanical rather than motorized interpretation. In general he advocated the Swedish method of gymnastics, so it is even more surprising to find this type of reasoning in his works. But this might simply highlight the strength of the mythological system and its powers of control.

The whole of the chapter quoted above is based on a "motorized" interpretation of the human body and analysing it takes up fifty pages. It can also be observed that in his foreword Tissié very faithfully followed Demenÿ. On the question of setting up an industrial order: "Physical education must be seen in terms of the increase in energy it will bring the Nation. Its broader purpose is to increase our industrial capacity in the world economy. If physical education is understood in this manner, it will fulfil a vital function in society $[\ldots]$ The human engine produces effort. The worker is the owner and employer of his own living machine. For him, it represents the capital that he is investing in his employment contract, especially when this machine comes into contact with the great 
industrial machine of his employers, either through union with it or by opposition to it. Strikes arise more often than not from the antagonism that exists between these two machines. [...] It is therefore through a rationalized use of physical education that powerful human engines can be created to provide a greater quantity of energy and economic output. Creating human machines is part of this phase of constitution" (Tissié, 1919, p.4).

We could quote practically the whole of the foreword. Here Tissié, surely unconsciously, is echoing Taylor and the logic of the human industrial internal combustion engine. He demonstrates that workers would be happier if they were better trained to make use of their energy capital. He also believes that this would favor social harmony. And so he advocates a system of control over the body that is bound to have repercussions on the institutions of the day (and this, at least, is visible in the official texts) since he was himself a relatively important figure at this time. The methods suggested by Tissié were not however, accepted by the official authorities, as they were considered out-moded, even though he finally made reference to the current metaphors.

This paper perfectly illustrates the logic of the system we are trying to draw attention to. The texts on physical education and sport are in perfect harmony with the logic of the new structures that were being set up in the work place. These theories were applied more widely on the future working population through the imposition of a State requirement. The "human engine" was therefore doubtless only the corollary to secondary industrial production when perceived in terms of values and social control but its application was limited to the field of institutional school corporal education. The system of confinement in the factory described by Michèle Perrot would be transposed to corporal education and to the models used for interpreting it.

\section{Official texts discovered scientific metaphors}

Most of the State handbooks and texts that appeared between 1908 and 1960 bore witness to this desire to apply the energy-producing image and the metaphor of the mechanized human body to the population in general. We quote as examples A Handbook of Physical Exercises and Games for Schools (Manuel d'exercices physiques et de jeux scolaires) of 1908, which was strongly influenced by Georges Demenÿ and published by the Ministry of Public Instruction and Fine Arts, as well as those published by the Ministry of War - the 1910 edition of The Rules of Physical Education (Règlement d'Education 
physique) and The Project for the General Rules of Physical Education: The French Method (Projet de Règlement Général d'Education physique : Méthode Française 19191923), followed by French Method General Rules (Règlement Général Méthode Française) from 1925 - 1931. We can see that for the Republican State it really was a matter of building the bodies of the general population, of the greatest number of people, particularly through the system of public, free and non-religious schools that was originated by Jules Ferry, through the standards and control methods of this system, and also through the army (at this time military service lasted two and a half years).

The last texts from the period just before the Second World War that employed this model are those to be found in the monumental Treatise on Physical Education (Traité $d^{\prime}$ Education physique). These two volumes of more than six hundred pages were entrusted in 1930to the editorship of M. Labbé. Labbé was a very important figure in the field of State physical education and a member of several ministerial committees, as were most of the contributors to the Treatise. The article written by Professor Dechambre and entitled "Training the living engine" was a perfect illustration of this.

This is what he wrote: "In living engines, as in man, training is the means that enables the individual to supply the maximum muscular effort with minimum fatigue" (Prof. Dechambre in M. Labbé's publication, p.159). The editor agreed with this point of view but his analysis was a little dated as he continued to use the steam engine as his metaphoric model in another article in the same edition entitled "Muscular energy". "Man produces energy. That energy is provided by his food, which he transforms, just as a steam engine transforms coal, (our italics), using up the latent element and liberating it in the form of heat and movement" (Labbé, 1930, p.292).

\section{Physical Education and factory production - any difference?}

In 1923 Jules Amar published a paper quite specifically designed for training industrial workers. Its title was The Human Engine and the Scientific Basis of Professional Work (Le moteur humain et les bases scientifiques du travail professionnel). It is interesting to mention this work to show how the same value system and the same mythological system underpinned both types of language. It was this value system that facilitated the interpretation of the perception of energy in physical education, up to the 1950s and 1960s.

Jules Amar writes: "the human engine is probably an electrocapillary engine, in 
which the surface tension is modified and a contraction produced by stimulating the nerves [...]. Man's power, which is at best only equal to $1 / 7$ horsepower, cannot be compared to the power of our modern engines. But the human engine is very productive and only uses up 8 tiny calories for a kilogram per meter produced, which is equal to a rate of productivity of 30\%" (Amar, 1923, p.669). Amar here laid down the foundations on which Astrand was subsequently to construct his own theories (highly significant theories appeared at the end of the 1970s enabling the body to be interpreted in terms of Maximum Aerobic Speed, Maximum V.O.2 and Maximum Aerobic Force), and which also formed the basis, for the Luc Léger and Cooper tests (which, as already mentioned, are still used in sports training today) among others.

In all these cases, 'man' is reinvented as an efficient engine following the logic of the industrial system: "Man the worker, has a longer working life than inanimate machines; for example, the most sophisticated steam engine can only remain serviceable for fifteen or twenty years without requiring repairs [...] Engines that compare with man's mobile perfection are very few and far between" (ibid., p.670). The objective here was to transform this natural perfection into an artificial engine. Under these conditions, the population as a whole "[...] could normally increase its 'level of social usefulness', by using initiative, willpower and 'personal' energy" (ibid., p.672).

\section{From engine to endurance: nature as counterfeit energy}

At the same time, in 1925, Georges Hébert - who also played an important role in developing State physical education (see Bui-Xuân \& Gleyse, 2001) - in his Sport Versus Physical Education (Le sport contre l'éducation physique) while based on the idea of a natural method and being critical of "science as the be-all and end-all" and of "productivity at all costs", also used this system of values and constraints, when he compared 'man' first to an automobile and then to a steamship (Hébert, 1946, reedited. pp. 62-77). The passage that spreads over several pages comparing man to a "steamer", was particularly concerned with wear and tear and overheating of parts as well as with over consumption of coal, thus showing that an ill-considered effort (such as is made in sport) could lead to rapid deterioration of the machine and total exhaustion, whereas a reasonable effort as in "physical education" would result in the depletion of reserves at a much more acceptable rate and with no damage to the machine either. The spirit guiding the way this study was 
conducted is easily seen. This does not diminish the fact that 'man' really was being compared with the boiler of a steamship.

In any case, the motto that appeared on the cover of all of Hébert's publications: "be strong, be useful" matches this logic perfectly. 'Man' was considered in purely utilitarian terms and consequently became a tool of society and even sometimes the instrument of the economy, even when this might appear to go against quite a number of Hébert's own propositions.

It should also be emphasized that while Georges Hébert challenged practically all forms of "scientism" in physical education, his exceptional references to researchers encompassed Fernand Lagrange and Georges Demenÿ, which would tend to show the strength of the system of control and its importance too in the field of physical education and sport in school.

In the foreword to his introduction (volume I of Physical and Moral Education by the Natural Method (Education physique et morale par la méthode naturelle)) he leaves us in no doubt of this, even though the metaphor of the 'man-engine' has disappeared: "But to begin with, it is essential, as I said before, to recover all our natural gestures little by little and to learn to work with greater productivity in mind" (Hébert, 1936, p.VI).

Paradoxically, however, in advocating a Natural Method, Georges Hébert rediscovered a system of totally "artificial" control resulting from the theoretic reflexes in the steam engine and then in the factory and industrial production. Hence Hébert's example enables the effectiveness of the language system to be understood. Even rejected in principle, it reemerged in theory with specific proposals.

\section{Human engines everywhere?}

Beyond the specific field of P.E. are examples proving that this system of control was spreading. A 1957 edition of What do I know? (Que sais-je ?), a popular and widely read French publication, written by P.Chauchard and entitled The Living Engine (Le moteur vivant) incorporates what is perhaps one of the last traces of a logic that will gradually be replaced by another form of instrumental rationalization, as society passes into the postindustrial period (Touraine A., 1969). This new logic will be based on the model of the computer (see Gleyse, 1995 and 1997), information and possibly even "entertainment" (Debord, 1967), but here we digress. 
In analyzing the language applied to the body, this process has been described as a "cognomorphosis" (Gleyse, 1995), in other words as a process that progresses from a system of scarcely internalised material constraints, to an increasingly abstract system of constraints that are nevertheless more internalised. J. Paillard's article - an influential figure in physical education and ergonomics in the 1970s, from its very title Piloting the human machine (Le pilotage de la machine humaine) - can be seen as a transition between these two models. In this case, the system of confinement and micro control has been accepted and integrated by individuals. In France, by the 1970s onwards, the metaphor of the biological computer has taken over from that of the human engine. But that is an invitation to a more up-to-date story of the discipline, possibly to be told later.

\section{CONCLUSION}

The facts recounted above enable evidence of the emergence of a system of bodily control to be brought to light, a system that was related to the development of secondary industry and that gradually incorporated a physical education and sports discourse expressed by means of a mechanical metaphor. Be that as it may, it has been shown that there were significant time lags between technical innovation, scientific theory and the metaphors resulting from this domain being expressed in school programs and State policies.

This article is not an attempt at a general history of physical education in France which has already been conscientiously developed by several other authors, but it does aim to meticulously examine the specific language used to describe norms and models employed to explain the body, language on this subject that is reused and thus may be deemed, as with any discourse, to have an effective function; in other words, to be a language that has practical efficacy in reality.

We have thus examined the discourse of numerous authors as being a system of micro power in the sense that Foucault employed the term. Clearly, there is no absolute certainty of the efficacy of such metaphors. Their concomitant with the Second Industrial Revolution (concerned with the introduction of the factory and not just with the manufacturing process) remains both comprehensible and troubling. But it is interesting to see that in renewed forms this relationship has been perpetuated over the course of time.

Perhaps this contributes even more to validating the "hologram" effect, specific to everything that concerns human knowledge, defined by Edgard Morin and according to 
which "if the parts are in everything, everything is in the parts too" (Morin, 1986, p.98 passim). To some extent, it is possible to rediscover here the positions of David Kirk and Marcel Mauss when they defined the body in 1951 as "a total social fact". The examination of machine metaphor in physical education in France is particularly interesting for the degree to which it might show that the subject is an integral part of society and culture.

Finally, if we accept the idea advocated by Pierre Fougeyrollas (1991), which affirms that "modernity" is based on "the reign of reason" and "supremacy over nature", the instrumental rationalization of the body, as a part of nature, is part of a greater logic that goes beyond the simple level of the literature on the body. If we agree that the body is "the floating signifier" (Brohm, 1989, p.399) then the language used when referring to the body and to corporal practices can only be a perfect illustration of the overall structure that makes up the system of values that constitute modernity. This language reveals the systems of controls and standards that organize the fabric of society, its very skin.

But the paradigm of the human engine seems to us to be perfectly illustrated in the analysis made by Alain Touraine in 1992 in his A Critique of Modernity (Critique de la modernité) as the supremacy of instrumental rationalization over subjectivity. In other words, to be a system under which a certain number of influential figures consider others more as rational instruments than as individuals in their own right. Of course, we can also find the ideas of normality, micro control and even confinement that were first brought to light by Michel Foucault.

Through our interpretation in this article of a localized and individual language (used by people concerned with the institution of physical education from the mid-19th century to the end of the 1950s) we have attempted to lay the first stepping stones for a possible new analysis of the process of instrumental rationalization of the body both at school and throughout the whole of society. 


\section{Bibliography and Selected Reading}

AMAR J. (1923) Le Moteur humain et les bases scientifiques du travail professionnel (Paris, Dunod). ANDRIEU G. (1990) L'éducation physique au XXe siècle: une histoire des pratiques (Paris, Bazina). ARNAUD p.(1983) Les Savoirs du corps (Lyon, PUL).

ARNAUD p.(1987) Les Athlètes de la république. Gymnastique, sport et idéologie républicaine, 18701914 (Toulouse,Privat).

BELTRAN A., \& GRISET p.(1990) Histoire des techniques au XIXème et XXème siècles (Paris, Armand Colin).

BERT p.(1870) Leçons sur la physiologie comparée de la respiration (Paris, Ballières).

BLOCH M. (1936) Les techniques, l'histoire et la vie, Les Annales, 32 (Nov.), (Paris, Armand Colin), pp.513-515.

BOIGEY M. (1924) Physiologie de l'Education physique. in Coll. Encyclopédie des sports Tome I, (Paris, Librairie de France), pp. 253-292.

BOLOT, no first name (1920) La Machine humaine (Paris, Fournier).

BOUDET J., \& AMALRIC J. (1986) Grand Larousse Encyclopédique (Paris, Hachette).

BRETON P., RIEU M.-A., \& TINLAND F.(Eds.) (1990) La Techno-science en question. Eléments pour une archéologie du XXe siècle (Seyssel, Champ-Vallon).

BROHM J.-M. (1976) Corps et politique (Paris, Delarge).

BROHM J.-M. (1989) Philosophie du corps. Quel corps?, in Coll. Encyclopédie Philosophique universelle, Tome I, L'univers philosophique (Paris, P.U.F.), pp. 399.

BUI-XUAN G. (1989) Les Ècoles Michelin optent pour la méthode naturelle. in p.ARNAUD, J.-P. CLEMENT, \& M. HERR. (Eds.) Education physique et sport en France, 1920-1980 (Clermont-Ferrand, AFRAPS), pp. 61-77.

BUI-XUAN G.,\& GLEYSE J. (2001) L'Emergence de l'Education physique. George Demenÿ et Georges Hébert (Paris, Hatier).

CANGUILHEM G. (1989) La Connaissance de la vie (Paris, Vrin).

CHAUCHARD p.(1957) Le Moteur vivant (Paris, P.U.F).

CHAUVEAU A. (1855) Traité d'anatomie comparée (Paris, Baillères).

COLL. (1997) Corps et Culture. Plaisirs du corps et plaisirs du corps, 2, (Montpellier, Corps et culture).

COLL. (1998) Corps et Culture. Sport et lien social, 3, (Montpellier, Corps et culture).

COLL. (1999) Corps et Culture. Corps, Sports et rites, 4, (Montpellier, Corps et culture).

COLLINET C. (2000) Les Grands courants d'éducation physique en Frnace (Paris, PUF).

COUVREUR E. (1890) Les Exercices du corps (Paris, Baillères).

DEBORD G. (1967) La Société du spectacle (Paris, Gallimard).

DEMENŸ G. (1890) De la précision des méthodes d'Education physique. Revue Scientifique, T. XX, (Paris, Bureau des revues), 2ème semestre, 12, pp. 354-359.

DEMENŸ G. (1902, reed. 1931) Les Bases scientifiques de l'Education Physique. (Paris, F. Alcan).

DEMENŸ G. (1905) Sur l'Evaluation de l'Education physique en France, Revue Scientifique, 2, (Paris, Bureau des revues), 1er semestre, pp. 394-398.

DUBUISSON M., AUDIN M., \& DAUMAS D. (1979) Histoire générale des techniques, Tomes III et IV, (Paris, PUF).

DURAND J.-P. \& MERRIEN F.- X. (1991) Sortie de siècle (Paris, Vigot).

ELIAS N. (1973) La Civilisation des mœurs (Paris, Fayard Poche).

FOUCAULT M. (1966) Les Mots et les choses, (Paris, Gallimard).

FOUCAULT M. (1969) L'Archéologie du savoir (Paris, Gallimard).

FOUCAULT M. (1975) Surveiller et punir (Paris, Gallimard).

FOUCAULT M. (1994) Dits et Ecrits, 4 tomes (Paris, Gallimard).

FOUGEYROLLAS p.(1991) L’Attraction du futur (Paris, Méridien Kliensieck).

FOURASTIE J. (1979) Les Trente glorieuses, ou la Révolution invisible de 1946 à 1975 (Paris, Fayard). FRIEDMANN G. (1950) Où va le travail humain ? (Paris, Gallimard).

GLEYSE J. (1991) Corps et technologie. Approche épistémologique des concepts. In MIDOL N., (Ed.) Actes du colloque de Nice, Performance et Santé, (Nice, AFRAPS), pp. 83-89.

GLEYSE J. (1992) Corps, techniques et sciences. Quelques éléments d'archéologie, de l'âge classique à la post-modernité, S.T.A.P.S., 29, (Grenoble, AFRAPS), pp. 43-55.

GLEYSE J. (1993) Archéologie de la cognomorphose d'un champ, in: G. BUI-XUAN, \& J. GLEYSE 
L'identité de l'Education physique, (Clermont, AFRAPS).

GLEYSE J. (1995) Archéologie de l'Education physique au XXe siècle en France. (Paris, P.U.F).

GLEYSE J. (1997) L'Instrumentalisation du corps (Paris, Montréal, L'Harmattan).

GUAY D. (1981) L'Histoire de l'éducation physique au Québec (Montréal, Gaëtan Morin).

GUAY D. (1969). L'Education physique dans les écoles normales au Québec. 1836-1969, (Montréal, Emprest).

GUAY D. (2000). La Conquête du sport (Montréal, Lanctôt).

GUAY-LESCOT J.-L. (1999) Education et sport scolaires durant l'entre-deux-guerres (1919-1939): des textes à la réalité, In GLEYSE J. L'Education physique au XXe siècle: approches historique et culturelle (Paris, Vigot), pp. 59-68.

GOUNOT A., NIEWERTH T., \& PFISTER G. (Eds.) (1995). Welt der spiele. Politische, soziale und pedagogische Aspekte (Berlin, Academia).

GUIGOU J. (1987) La cité des Egos (Grenoble, L'impliqué).

HABERMAS J. (1973) Connaissance et intérêt (Paris, Gallimard).

HEBERT G. (1925) Le Sport contre l'Education physique (Paris, Vuibert).

HEBERT G. (1936) L'Education physique virile et morale par la méthode naturelle, Tome I. (Paris, Vuibert).

HIRN G. A. (1862) Théorie mécanique de la chaleur (Paris, Lieber).

HIRN G. A. (1863) Exposition analytique et expérimentale de la théorie de la chaleur (Paris, Mallet Bachelet).

HIRN G.A. (1887) La thermodynamique et le travail chez les êtres vivants, Revue scientifique, 22, May, (Paris, Bureau des revues), pp. 673-684.

HITER A. (1945) La machine humaine (Paris, Delagrave).

HCENIG H. (1911) La pratique des exercices physiques (Paris, Baillères).

Holt R. (1991), Women, Men and Sport in France, c. 1870-1914: An Introductory

Survey, Journal of Sport History, 18:1 (Lemon, P.A., USA, North American Society for Sport History), pp. 121-134.

KANO J. (1995). Scritti del Fondatore: Judo Kyohon. In Kyu-Shin Do (Ed.), Quaderni del Bu-Sen, 3, (Milano, Enaudi), pp. 144-191.

KIRK D. \& TINNING R. (1990) Physical education, curriculum and culture (Taylor \& Francis book, London).

KIRK D. (1998) Schooling bodies. School practice and Public discourse, 1880-1950 (Continuum International Publishing Group, London).

KOYRE A. (1973) Etudes d'histoire de la pensée scientifique (Paris, Gallimard Tel.)

LABBE M. (1930) Traité d'Education physique, 2 T. (Paris, Doin).

LAGRANGE F. (1888) La fatigue et l'entraînement. Revue Rose, Revue Scientifique, T. XV, 1er semestre, (Paris, Bureau des revues), pp. 203-211.

LAGRANGE F. (1888) L'Ėducation physique des jeunes enfants, Revue Rose, Revue Scientifique, T. XVI, 2ème semestre, (Paris Bureau des revues), pp. 632-638.

LAGRAnGe F. (1888) Physiologie des exercices du corps (Paris, F. Alcan).

LEROI-GOURHAN A. (1964) Le geste et la parole (Paris, Seuil).

LIOTARD p.(1999) Du discours à la croyance. L'éducation physique au XXe siècle (Thèse, Lyon, non publiée).

MAREY E.-J. (1868) Du Mouvement dans les fonctions de la vie (Paris, Germer-Baillères).

MAREY E.-J. (1873) La Machine animale. Locomotion terrestre et aérienne (Paris, Germer-Baillères).

MARTIN J.-L. (1999) La Politique de l'éducation physique sous la Ve République. 1 L'élan gaullien (Paris, PUF).

MARX K. (1962) Manuscrits de 1844 (Paris, Editions Sociales).

MELLOR P.A., \& SHILLING C. (1993) Re-forming the body (London, Sage).

MORIN E. (1986) La Connaissance de la connaissance (Paris, Seuil).

MUMFORD L. (1973) Le Mythe de la machine. (Paris, Plon).

PAILLARD J. (1977) La machine organisée et la machine organisante, Revue de l'Education physique belge, 27, pp. 19-48.

PAILLARD J. (1982) Le pilotage du moteur musculaire. In, G.AZEMAR \& H.RIPOLL (Eds), Eléments de neurobiologie des comportements moteurs (Paris, INSEP), pp. 9-35.

POCIELLO C. (1981) Sports et société (Paris, Vigot).

RAUCH A. (1983). Le souci du corps. Paris: PUF. 
RAUCH A., (1982) Le Corps en Education physique (Paris, PUF).

RUSSO F. (1986) Introduction à l'histoire des techniques (Paris, Métailler).

SHEHU J. (1996) Sport Education: Ideology, Evidence and Implications for Physical Education in Africa Sport Education and Society (Carfax, London), pp. 227-237.

SHILLING C. (1993) The Body and social theory (London, Sage).

SHUTTLEWORTH.\& WAN-KA C. (1998) Youth, Sport, Education and Development in Hong Kong: A Conflict Model Social Impact Assessment, Sport, Education and Society, 3: 1 (Carfax, London), pp 37-59.

SYNNOT A. (1993) The Body Social (London, Routledge).

THOM R. (1990) Apologie du logos (Paris, Fayard).

TISSIE p.(1919) L'Education physique et la race. Santé, travail, longévité (Paris, Flammarion).

TOURAINE A. (1992) Critique de la modernité (Paris, Fayard).

TURNER B.S. (1997) Medical Power and Social Knowledge (second edition, London, Sage).

VIGARELLO G. (1978) Le Corps redressé (Paris, Delarge). 